Article

\title{
New Mastoparan Peptides in the Venom of the Solitary Eumenine Wasp Eumenes micado
}

Katsuhiro Konno ${ }^{1, *}$, Kohei Kazuma ${ }^{1,+}$, Marisa Rangel ${ }^{2}$, Joacir Stolarz-de-Oliveira ${ }^{3}$, Renato Fontana ${ }^{4}$ (D), Marii Kawano ${ }^{5}$, Hiroyuki Fuchino ${ }^{5}$ D , Izumi Hide ${ }^{6}$, Tadashi Yasuhara ${ }^{7}$ and Yoshihiro Nakata ${ }^{8}$

1 Institute of Natural Medicine, University of Toyama, Toyama, Toyama 930-0194, Japan; cokazuma@kumamoto-u.ac.jp

2 Immunopathology Laboratory, Butantan Institute, Sao Paulo SP 05503-900, Brazil; marisarangel2112@gmail.com or mrangel@usp.br

3 Laboratory of Physiology and Animal Toxins, Federal University of West Pará, Santarém PA 68040-070, Brazil; Joacir.ufopa@gmail.com

4 Department of Biological Sciences, State University of Santa Cruz, Ilhéus BA 45662-900, Brazil; rfontana@uesc.br

5 Research Center for Medicinal Plant Resources, National Institutes of Biomedical Innovation, Health and Nutrition, Tsukuba, Ibaraki 305-0843, Japan; marii@nibiohn.go.jp (M.K.); fuchino@nibiohn.go.jp (H.F.)

6 Department of Molecular and Pharmacological Neuroscience, Graduate School of Biomedical and Health Sciences, Hiroshima University, Hiroshima, Hiroshima 734-8551, Japan; ihide@hiroshima-u.ac.jp

7 Laboratory of Microbial Chemistry, School of Pharmacy, Kitasato University, Minato-ku, Tokyo 108-8641, Japan; yasuharat@pharm.kitasato-u.ac.jp

8 Department of Pharmacology, Hiroshima University Graduate School of Biomedical \& Health Sciences, Hiroshima 734-8553, Japan; ynakata@hiroshima-u.ac.jp

* Correspondence: kkgon@inm.u-toyama.ac.jp; Tel.: +81-76-434-7617

+ Present address: Eco-Frontier Center of Medicinal Resources, School of Pharmacy, Kumamoto University, Kumamoto, Kumamoto 862-0973, Japan.

Received: 12 January 2019; Accepted: 5 March 2019; Published: 10 March 2019

Abstract: Comprehensive LC-MS and MS/MS analysis of the crude venom extract from the solitary eumenine wasp Eumenes micado revealed the component profile of this venom mostly consisted of small peptides. The major peptide components, eumenine mastoparan-EM1 (EMP-EM1: LKLMGIVKKVLGAL-NH${ }_{2}$ ) and eumenine mastoparan-EM2 (EMP-EM2: LKLLGIVKKVLGAI-NH ${ }_{2}$ ), were purified and characterized by the conventional method. The sequences of these new peptides are homologous to mastoparans, the mast cell degranulating peptides from social wasp venoms; they are 14 amino acid residues in length, rich in hydrophobic and basic amino acids, and C-terminal amidated. Accordingly, these new peptides can belong to mastoparan peptides (in other words, linear cationic $\alpha$-helical peptides). Indeed, the CD spectra of these new peptides showed predominantly $\alpha$-helix conformation in TFE and SDS. In biological evaluation, both peptides exhibited potent antibacterial activity, moderate degranulation activity from rat peritoneal mast cells, and significant leishmanicidal activity, while they showed virtually no hemolytic activity on human or mouse erythrocytes. These results indicated that EMP-EM peptides rather strongly associated with bacterial cell membranes rather than mammalian cell membranes.

Keywords: solitary wasp; venom; mastoparan peptide; linear cationic $\alpha$-helical peptide; amphipathic $\alpha$-helix structure.

Key Contribution: Chemical and biological characterization of new mastoparan peptides in the venom of solitary eumenine wasp Eumenes micado. 


\section{Introduction}

Mastoparan was first isolated from the venom of the vespid wasp Paravespula lewisii as a mast cell degranulating and histamine-releasing principle [1]. Since then, a number of closely related peptides have been found in a variety of social wasp venoms (hornets and paper wasps) [2,3], and they are collectively called mastoparans or mastoparan peptides. The mastoparans are 14 amino acids in length with the C-terminus amidated, and rich in hydrophobic and basic amino acids, which leads to amphipathic chemical character, adopting $\alpha$-helical secondary structure under proper conditions. This chemical feature is essential for their biological activities associated with the cell membrane, showing histamine releasing from mast cells, and antimicrobial and hemolytic activities. Due to these biological properties, mastoparans have been developed not only for pharmacological research tools but also for therapeutic use, in particular, as a new type of antimicrobial agents [4-6].

In our survey of bioactive substances in solitary wasp venoms [7], we found a mastoparan peptide in the Eumenine wasp venom for the first time in 2000. It is eumenine mastoparan-AF (EMP-AF) from Anterhynchium flavomarginatum micado, which has all the chemical and biological characteristics of mastoparans [8-10]. EMP-OD (OdVP1) is the second mastoparan to be found in the Eumenine wasp venom of Orancistrocerus drewseni [11,12]. This wasp venom has another mastoparan peptide, OdVP3 [12]. Three other Eumenine wasp venoms have mastoparan peptides: EMP-ER from Eumenes rubrofemoratus, EMP-EF from Eumenes fraterculus, and EpVP2a and EpVP2b from Eumenes pomiformis $[13,14]$. The sequences of these mastoparan peptides are summarized in Table 1.

Table 1. Mastoparan peptides in wasp venom.

\begin{tabular}{llll}
\hline \multicolumn{1}{c}{ Mastoparan } & INLKALAALAKKIL-NH $_{\mathbf{2}}$ & \multicolumn{1}{c}{ EMP-AF } & \multicolumn{1}{c}{ INLLKIAKGIIKSL-NH $_{\mathbf{2}}$} \\
\hline EMP-EF & FDVMGIIKKIASAL-NH & EMP-OD & GRILSFIKGLAEHL-NH \\
EMP-ER & FDIMGLIKKVAGAL-NH & OdVP3 & KDLHTVVSAILQAL-NH \\
EMP-EM1 & LKLMGIVKKVLGAL-NH & EpVP2a & FDLLGLVKKVASAL-NH \\
EMP-EM2 & LKLLGIVKKVLGAI-NH & EpVP2b & FDLLGLVKSVVSAL-NH \\
\hline
\end{tabular}

Thus, eumenine wasp venoms may have mastoparans in common. The major role of solitary eumenine wasp venom is to paralyze their prey, the caterpillar. Accordingly, these peptides may not contribute to this major role, but have a supporting role in acting as antimicrobials and potentiating the venom toxicity by disturbing excitable membranes, such as similar peptides in spider and scorpion venoms [15].

In our continuing survey of solitary wasp venoms, we found another mastoparan peptide in the venom of Eumenes micado. This species is one of the most common Eumenine wasps in Japan. It also belongs to the potter wasps group because they build a potter shaped nest with mud. In this study, we first investigated the LC-MS profile, revealing the major components are mastoparan peptides. Then, they were isolated and their sequences were determined by the conventional method. The results of biological evaluation by using synthetic specimens are also reported.

\section{Results}

\subsection{On-Line Mass Fingerprinting by LC-MS}

The crude venom extract was first subjected to LC-ESI-MS in order to know the component profile-how many components are contained and what type of molecules are they. The TIC is shown in Figure 1A. The volume of the sample solution never exceeded $10 \%$ amount of crude venom from a single specimen, which is sufficient for LC-ESI-MS analysis (mass fingerprinting and peptide sequencing). On-line mass fingerprint was prepared from TIC by "virtual fractionation", i.e., collecting MS spectra from certain ranges of retention time, and then the molecular mass was analyzed in each fraction. The results are summarized in Table 2. A total of 93 molecular mass units were found from 18 virtual fractions. The low molecular mass components $(m / z 90-300)$ may be free amino 
acids, biogenic amines, and nucleic acids, and those of $m / z$ range 300-5000 should be peptides, in particular, $m / z 500-2000$ accounts for $48 \%$, implying that major components in this venom are relatively small peptides.
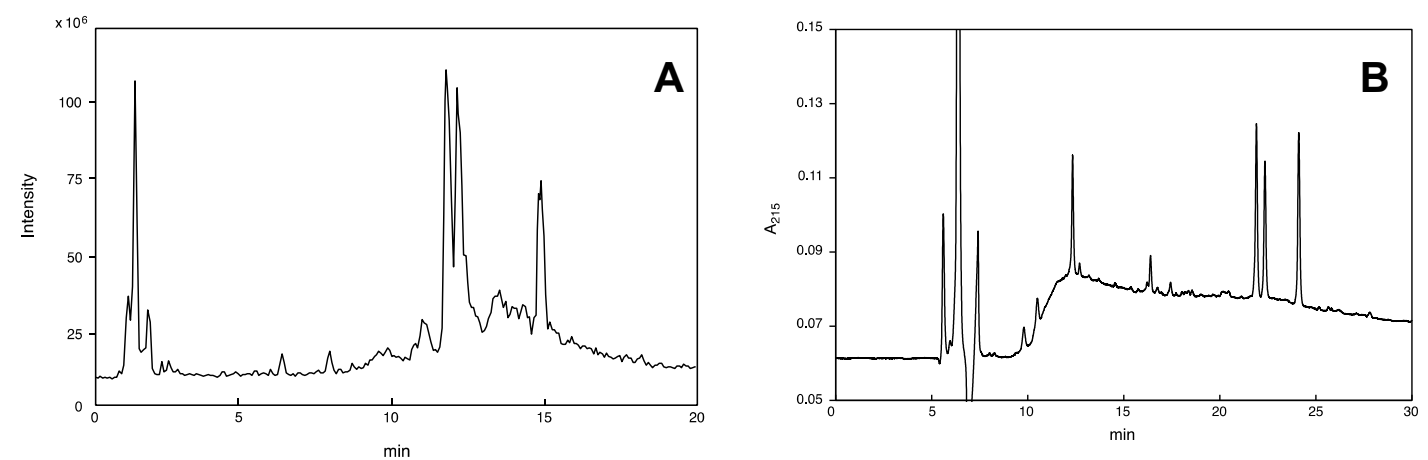

Figure 1. (A) TIC profile from LC-ESI-MS of venom extracts of Eumenes micado, injected with $10 \%$ of crude venom extract of a single specimen to reverse-phase HPLC using CAPCELL PAK $\mathrm{C}_{18}(1.5 \times$ $150 \mathrm{~mm}$ ) with linear gradient of 5-65\% $\mathrm{CH}_{3} \mathrm{CN} / \mathrm{H}_{2} \mathrm{O} / 0.1 \%$ formic acid over $20 \mathrm{~min}$ at flow rate of $200 \mu \mathrm{L} / \mathrm{min}$. (B) Fractionation of venom extracts of Eumenes micado by reverse-phase HPLC using CAPCELL PAK $\mathrm{C}_{18}(10 \times 250 \mathrm{~mm})$ with linear gradient of $5-65 \% \mathrm{CH}_{3} \mathrm{CN} / \mathrm{H}_{2} \mathrm{O} / 0.1 \%$ TFA over $30 \mathrm{~min}$ at flow rate of $2.5 \mathrm{~mL} / \mathrm{min}$. UV absorption was monitored at $215 \mathrm{~nm}$.

Table 2. On-line mass fingerprinting of crude venom extract from Eumenes micado by LC-ESI-MS.

\begin{tabular}{|c|c|c|}
\hline Fr. No. & Retention Time (min) & {$[\mathbf{M}+\mathbf{H}]^{+} m / z$} \\
\hline 1 & $1.0-1.5$ & $\begin{array}{l}90.054,106.049,112.086,116.070,118.085,120.065,147.076,147.112, \\
148.060,156.076,175.118,184.072,487.358\end{array}$ \\
\hline 2 & $1.5-2.0$ & $\begin{array}{l}132.101,150.057,182.080,268.102,269.087,284.097,317.239,336.157, \\
339.237,348.068,361.206,374.324,418.314,664.113\end{array}$ \\
\hline 3 & $2.0-3.0$ & $166.085,428.035$ \\
\hline 4 & $3.0-4.0$ & $302.206,320.162,359.227,756.532$ \\
\hline 5 & $4.0-5.0$ & $346.232,372.258,473.306,999.663,1080.504,2064.020$ \\
\hline 6 & $5.0-6.0$ & $599.421,955.662,1029.681,1316.626$ \\
\hline 7 & $6.0-7.0$ & $471.326,543.383,939.669,1011.722$ \\
\hline 8 & $7.0-8.0$ & $589.331,883.631,901.584,969.639,2257.190,2413.290,3225.613,4898.1853$ \\
\hline 9 & $8.0-9.0$ & $582.256,931.577,996.686,1050.594,1109.697,1125.691,1241.615,1510.765$ \\
\hline 10 & $9.0-10.0$ & $564.299,1046.653,1973.176,2039.289$ \\
\hline 11 & $10.0-10.4$ & $940.575,1074.226,1449.976,2607.505$ \\
\hline 12 & $10.4-11.4$ & $918.559,1350.095,1368.902,1497.980$ \\
\hline 13 & $11.4-12.0$ & $815.497,1222.854,1481.986,1539.990$ \\
\hline 14 & $12.0-12.5$ & 1464.032 \\
\hline 15 & $12.5-13.0$ & $2113.272,2095.261$ \\
\hline 16 & $13.0-14.0$ & $1518.894,2078.259$ \\
\hline 17 & $14.0-14.5$ & $1353.871,1345.833,1505.866,3564.943$ \\
\hline 18 & $14.5-15.2$ & $1500.941,1502.903,1558.943,1701.020,1703.984$ \\
\hline
\end{tabular}

\subsection{Identification of Small Molecules (Amino Acids, Biogenic Amines, and Nucleic Acids)}

A total of 25 small molecules ( 15 amino acids, 4 biogenic amines, 6 nucleic acids) were identified, as summarized in Table 3. It was done mainly by elemental composition analysis of molecular ions $(\mathrm{M}+\mathrm{H})^{+}$with an error limit of $0.005 \mathrm{Da}$. In some cases for the amino acids, iminium ion was concomitantly observed, analysis of which supported the identification. Concomitant observation of deamination $\left(-\mathrm{NH}_{3}\right)$ peak from molecular ions of biogenic amines was supportive as well. For nucleic 
acids (adenosine, AMP, ADP, and NAD), MS/MS spectra were obtained by data dependent MS/MS measurement, which confirmed the structure of these compounds.

Table 3. Small molecules in the crude venom extract from Eumenes micado by LC-ESI-MS.

\begin{tabular}{cl}
\hline Retention Time (min) & {$[\mathbf{M}+\mathbf{H}]^{+} \mathbf{m} / \mathbf{z}$} \\
\hline 1.10 & 112.086 (histamine), 147.112 (lysine), 156.076 (histidine) \\
1.24 & 175.118 (arginine) \\
1.31 & 90.054 (alanine), 106.049 (serine), 116.070 (proline), 118.085 (valine), \\
1.53 & 120.065 (threonine), 147.076 (glutamine), 148.060 (glutamic acid) \\
1.60 & 348.068 (AMP) \\
1.68 & 150.057 (methionine), 664.112 (NAD) \\
1.75 & 154.085 (dopamine) \\
1.83 & 132.101 (leucine/isoleucine), 138.090 (tyramine), 268.102 (adenosine) \\
1.98 & 182.080 (tyrosine) \\
2.21 & 269.087 (inosine), 284.097 (guanosine) \\
2.44 & 428.035 (ADP) \\
2.67 & 166.085 (phenylalanine) \\
4.30 & 122.096 (phenethylamine) \\
& 205.096 (tryptophan) \\
\end{tabular}

By conventional HPLC using a reverse-phase C18 column, analysis of these small molecules is not easy because they are eluted as a complex mixture in the front part of the solvent. Accordingly, derivatization or special HPLC conditions are needed for analysis [16-18]. In contrast, the method utilizing LC-MS as shown above is easy and advantageous, in that it can be applicable for small molecule analysis of any animal venom.

Previous studies reported the presence and function of some of these components in wasp venoms. Histamine was reported to be found in social and solitary wasp venoms, playing a role in the pain-producing component [16]. Adenosine is contained in spider wasp venom [19]. Dopamine is present in the venom of the emerald jewel wasp Ampulex compressa and implicated in a unique behavior of its prey, the American cockroach [18]. Most of the small molecules contained in this wasp venom would give physiological effects when injected into caterpillar prey, which remains to be studied.

\subsection{Peptide Sequencing by MS/MS Analysis}

Data dependent MS/MS measurement afforded MS/MS spectra from 50 peptide molecules. Manual sequence analysis of these MS/MS spectra revealed the full sequence of 43 peptides, and the rest of the 7 peptides were only partially sequenced (data not shown). The analyzed full sequences are shown in Table 4. The two most intense peaks in Fr. 13 and 14 contained the major peptides EMP-EM1 $\left(m / z\right.$ 1481.986, LKLMGLVKKVLGAL-NH ${ }_{2}$ : where L $=$ either $\mathrm{L}$ or I) and EMP-EM2 $(\mathrm{m} / \mathrm{z}$ 1464.032, LKLLGLVKKVLGAL-NH ${ }_{2}$ : where $\mathrm{L}=$ either $\mathrm{L}$ or I), respectively. They are different to each other only at position 4, L vs. M. The second intense peak in Fr. 18 contained two other mastoparan peptides (EMP-EM3: $m$ / $z$ 1500.940, FDLLGLLKKVVSGL-NH ${ }_{2}$; EMP-EM4: $m / z$ 1502.902, FDLGMLVKKVLAGL-NH ${ }_{2}$ : where $\mathrm{L}=$ either $\mathrm{L}$ or I).

These sequences can be classified according to homology and similarity. The majority are related to the major peptides EMP-EMs. As shown in Table 5, most of them are truncated peptides from both N- and C-terminus; in other words, they have a partial structure of EMP-EMs. Seemingly, these truncated peptides are cleavage products of EMP-EMs in some way, but it is not certain whether they are originally contained in the venom or not.

The rest of the peptides in this venom may be new peptides, as summarized in Table 6. All of these have no homology to any known peptides. 
Table 4. Peptide sequences analyzed from MS/MS spectra.

\begin{tabular}{|c|c|c|c|c|c|}
\hline Fr. No. & {$[\mathbf{M}+\mathbf{H}]^{+}$} & Sequence & Fr. No. & {$[\mathbf{M}+\mathbf{H}]^{+}$} & Sequence \\
\hline 2 & 361.206 & VVSG & 10 & $\begin{array}{r}564.299 \\
1046.653\end{array}$ & $\begin{array}{l}\text { FDLLG } \\
\text { FDLLGLLKK }\end{array}$ \\
\hline 4 & $\begin{array}{l}302.206 \\
320.162 \\
359.227 \\
756.532\end{array}$ & $\begin{array}{l}\text { LLG } \\
\text { LMG } \\
\text { VLQ } \\
\text { LVKKVLG }\end{array}$ & 12 & $\begin{array}{r}918.559 \\
1350.095 \\
1368.902 \\
1497.980\end{array}$ & $\begin{array}{l}\text { FDLGLLK } \\
\text { KLLGLVKKVLGAL-NH } \\
\text { KLMGLVKKVLGAL-NH }_{2} \\
\text { LKLmGLVKKVLGAL-NH }_{2}\end{array}$ \\
\hline 5 & $\begin{array}{l}346.232 \\
372.258 \\
473.306\end{array}$ & $\begin{array}{l}\text { LLT } \\
\text { LGAL-NH } \\
\text { VVSGL-NH } \\
\text { VI }\end{array}$ & 13 & $\begin{array}{r}815.497 \\
1222.852 \\
1481.986 \\
1539.990\end{array}$ & $\begin{array}{l}\text { PVGFLGLL } \\
\text { LLGLSLVLLGLLL-NH }_{2} \\
\text { LKLMGLVKKVLGAL-NH }_{2} \\
\text { LKLMGLVKKVLGALG }\end{array}$ \\
\hline 6 & $\begin{array}{r}599.421 \\
955.662 \\
1029.681\end{array}$ & $\begin{array}{l}\text { KVLGAL-NH }_{2} \\
\text { LLKKVVGSL-NH }_{2} \\
\text { LKKMGLVKK }\end{array}$ & 14 & 1464.032 & LKLGLVKKVLGAL-NH ${ }_{2}$ \\
\hline 7 & $\begin{array}{r}471.326 \\
543.383 \\
939.669 \\
1011.722 \\
\end{array}$ & $\begin{array}{l}\text { VLGAL-NH2 } \\
\text { LKLLG } \\
\text { LVKQKVLL-NH }_{2} \\
\text { LKLLGLVKK }\end{array}$ & 16 & 1518.894 & FDLGmLVKKVLAGL-NH ${ }_{2}$ \\
\hline 8 & $\begin{array}{l}589.331 \\
883.631 \\
901.584 \\
969.639\end{array}$ & $\begin{array}{l}\text { PVGFLG } \\
\text { LKLLGLVK } \\
\text { LKLMGLVK } \\
\text { LNLLKLAKG }\end{array}$ & 17 & $\begin{array}{l}1353.871 \\
1355.833\end{array}$ & $\begin{array}{l}\text { DLLGLLKKVVSGL-NH } \\
\text { DLGMLVKKVLAGL-NH } \\
\text { DL }\end{array}$ \\
\hline 9 & $\begin{array}{r}582.256 \\
931.577 \\
1109.697 \\
1125.691 \\
1241.615\end{array}$ & $\begin{array}{l}\text { FDLGM } \\
\text { TLKVGSLLT } \\
\text { VLNVLNVLL-NH }_{2} \\
\text { VLNTQNVLL-NH } \\
\text { LKLMGLVKKVL }\end{array}$ & 218 & $\begin{array}{l}1500.941 \\
1502.903 \\
1558.943\end{array}$ & $\begin{array}{l}\text { FDLLGLLKKVVSGL-NH } \\
\text { FDLGMLVKKVLAGL-NH } \\
\text { FDLLGLLKKVVSGLG }\end{array}$ \\
\hline
\end{tabular}

$\mathrm{L}=$ either $\mathrm{L}$ or $\mathrm{I} ; \mathrm{m}=$ methionine S-oxide.

Table 5. Peptides related to EMP-EMs.

\begin{tabular}{|c|c|c|}
\hline RT & {$[\mathbf{M}+\mathbf{H}]^{+}$} & Sequence \\
\hline \multicolumn{3}{|r|}{ EMP-EM1 } \\
\hline 7.16 & 901.584 & LKLMGLVK \\
\hline 6.02 & 1029.681 & LKLMGLVKK \\
\hline 8.81 & 1241.615 & LKLMGLVKKVL \\
\hline 1.88 & 336.157 & LmG \\
\hline 3.09 & 320.162 & LMG \\
\hline 3.32 & 756.532 & LVKKVLG \\
\hline 4.94 & 372.259 & LGAL-NH ${ }_{2}$ \\
\hline 6.55 & 471.326 & VLGAL-NH${ }_{2}$ \\
\hline 5.12 & 599.420 & KVLGAL-NH ${ }_{2}$ \\
\hline 10.65 & 1368.906 & KLMGLVKKVLGAL-NH ${ }_{2}$ \\
\hline 10.64 & 1497.980 & LKLmGLVKKVLGAL-NH $_{2}$ \\
\hline 11.72 & 1481.987 & $\begin{array}{l}\text { LKLMGLVKKVLGAL-NH } \\
\text { (EMP-EM1) }\end{array}$ \\
\hline 11.59 & 1539.995 & LKLMGLVKKVLGALG \\
\hline \multicolumn{3}{|r|}{ EMP-EM2 } \\
\hline 6.80 & 543.883 & LKLLG \\
\hline 7.64 & 883.631 & LKLLGLVK \\
\hline 6.47 & 1011.722 & LKLLGLVKK \\
\hline 3.63 & 302.206 & LLG \\
\hline 10.84 & 1350.095 & KLLGLVKKVLGAL-NH 2 \\
\hline 12.12 & 1464.032 & $\begin{array}{l}\text { LKLLGLVKKVLGAL-NH } 2 \\
\text { (EMP-EM2) }\end{array}$ \\
\hline
\end{tabular}


Table 5. Cont.

\begin{tabular}{|c|c|c|}
\hline RT & {$[\mathbf{M}+\mathbf{H}]^{+}$} & Sequence \\
\hline \multicolumn{3}{|r|}{ EMP-EM3 } \\
\hline 9.25 & 564.299 & FDLLG \\
\hline 10.77 & 918.559 & FDLLGLLK \\
\hline 9.54 & 1046.653 & FDLLGLLKK \\
\hline 1.73 & 361.206 & VVSG \\
\hline 4.73 & 473.305 & VVSGL-NH \\
\hline 5.35 & 955.662 & LLKKVVSGL-NH ${ }_{2}$ \\
\hline 14.42 & 1353.871 & DLLGLLKKVVSGL-NH $_{2}$ \\
\hline 14.76 & 1500.940 & $\begin{array}{l}\text { FDLLGLLKKVVSGL-NH } \\
\text { (EMP-EM3) }\end{array}$ \\
\hline 14.57 & 1558.951 & FDLLGLLKKVVSGLG \\
\hline \multicolumn{3}{|r|}{ EMP-EM4 } \\
\hline 8.83 & 582.256 & FDLGM \\
\hline 14.43 & 1355.833 & DLGMLVKKVVSGL-NH ${ }_{2}$ \\
\hline 13.50 & 1518.895 & FDLGmLVKKVVSGL-NH ${ }_{2}$ \\
\hline 14.89 & 1502.902 & $\begin{array}{l}\text { FDLGMLVKKVVSGL-NH } \\
\text { (EMP-EM4) }\end{array}$ \\
\hline
\end{tabular}

$\mathrm{L}=$ either $\mathrm{L}$ or $\mathrm{I} ; \mathrm{m}=$ methionine S-oxide.

Table 6. Unknown peptides.

\begin{tabular}{rrl}
\hline \multicolumn{1}{c}{ RT } & ${\text { [M }+\mathbf{H}]^{+}}$ & \multicolumn{1}{c}{ Sequence } \\
\hline 8.58 & 931.575 & TLKVGSLLT \\
8.51 & 1125.691 & VLNTQLNVLL-NH 2 \\
8.67 & 1109.697 & VLNVNLNVLL-NH \\
7.91 & 589.331 & PVGFLG \\
11.89 & 815.498 & PVGFLGLL \\
11.59 & 1222.851 & LLGLSLVLGLLL-NH \\
\hline
\end{tabular}

\subsection{Purification and Sequence Determination of Mastoparan Peptides}

Two major peptides, designated EMP-EM1 and EMP-EM2, were purified by reversed-phase HPLC (Figure 1B) in order to determine their sequences unambiguously. The fractions eluted at 21 and 22 min showed high purity, corresponding to EMP-EM1 and EMP-EM2, respectively. Edman degradation of EMP-EM1 revealed the 13 amino acid sequence as LKLMGIVKKVLGA, and the C-terminal L or I remained undetermined. Accordingly, the two possible structures, LKLMGIVKKVLGAL-NH ${ }_{2}$ and LKLMGIVKKVLGAI-NH ${ }_{2}$, were synthesized by solid-phase method, and the synthetic peptides were compared with natural peptide by HPLC behavior. It clearly showed only the former LKLMGIVKKVLGAL-NH $\mathrm{N}_{2}$ is identical with the natural one. Similarly, the structure of EMP-EM2 was unambiguously determined as LKLMGIVKKVLGAI-NH ${ }_{2}$. The sequences of two other mastoparan peptides EMP-EM3 and EMP-EM4 were not exactly determined because the HPLC fractionation did not give pure peptides, but instead, an inseparable mixture of these two peptides eluted at $24 \mathrm{~min}$.

The chemical features of EMP-EM1 and EMP-EM2, being rich in hydrophobic and basic amino acids with no disulfide bond, are characteristics of mastoparan peptides; in other words, linear cationic $\alpha$-helical peptides [15]. This class of peptides has been known to adopt an amphipathic $\alpha$-helical conformation, showing an amphiphilic character under appropriate conditions [10,20-22], and the amphipaticity of peptides has been considered essential for their biological activities [23]. In fact, if the helical wheel projection of EMP-EM1 and EMP-EM2 sequences were drawn, amphipathic $\alpha$-helical conformations could be possible, as depicted in Figure 2. Based on this view, all the hydrophilic amino 
acid residues (K) are located on one side, whereas the hydrophobic amino acid residues (M, I, L, and $\mathrm{V})$ are on the other side of the helix.

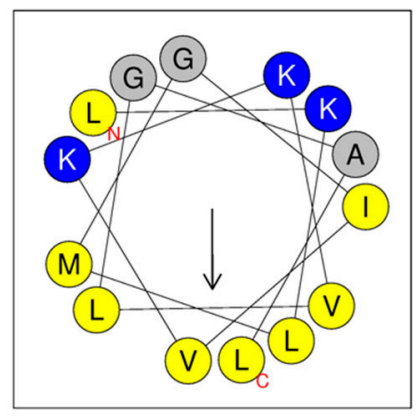

EMP-EM1

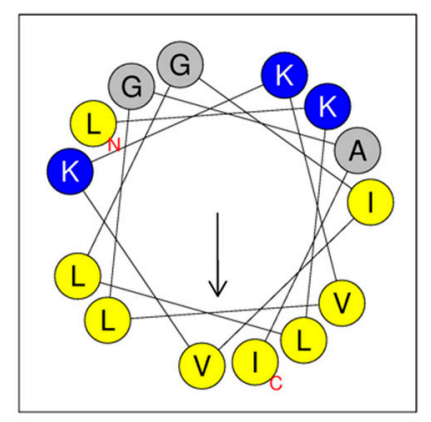

EMP-EM2

Figure 2. Helical wheel projection of the sequence of EMP-EM1 and EMP-EM2. In this view, through the helix axis, the hydrophilic Lys (K) residues are located on one side and the hydrophobic Val (V), Ile (I), and Leu (L) residues on the other side of the helix.

\subsection{Spectroscopy}

The mastoparan peptides are known to undergo a conformational change from a random coil to helical upon binding to lipid bilayers or in membrane mimetic environments $[9,24]$. The $\alpha$-helix content of these short chain peptides is directly related to favorable electrostatic interactions and the burial of the backbone into a more hydrophobic region. Figure 3 shows the CD spectra of EMP-EM1 and EMP-EM2 obtained in different environments to evaluate the relative importance of the electrostatic and hydrophobic contributions to the observed ellipticity. CD spectra obtained in water and in Tris/borate buffer, $\mathrm{pH} 7.5$, are characteristic of random coil conformation with a dichroic band around $198 \mathrm{~nm}$. In contact with an environment that mimics the anisotropic features of lipid bilayers as SDS suspension above critical micellar concentration ( $\mathrm{cmc}, 8 \mathrm{mM}$ ), the $\mathrm{CD}$ spectra exhibits two negative bands at 208 and $222 \mathrm{~nm}$ and an intense positive band at $192 \mathrm{~nm}$. The spectra were very similar to those obtained in a helical inducer environment of $40 \%$ TFE aqueous solution, and even in SDS below the cmc $(165 \mu \mathrm{M})$ (Figure 3). The ratio between observed ellipticities at $222 \mathrm{~nm}$ and $208 \mathrm{~nm}\left([\Theta]_{222} /\left[\Theta_{208}\right]\right.$ is $<1$ ) is indicative of the presence of the peptides as monomers [25].
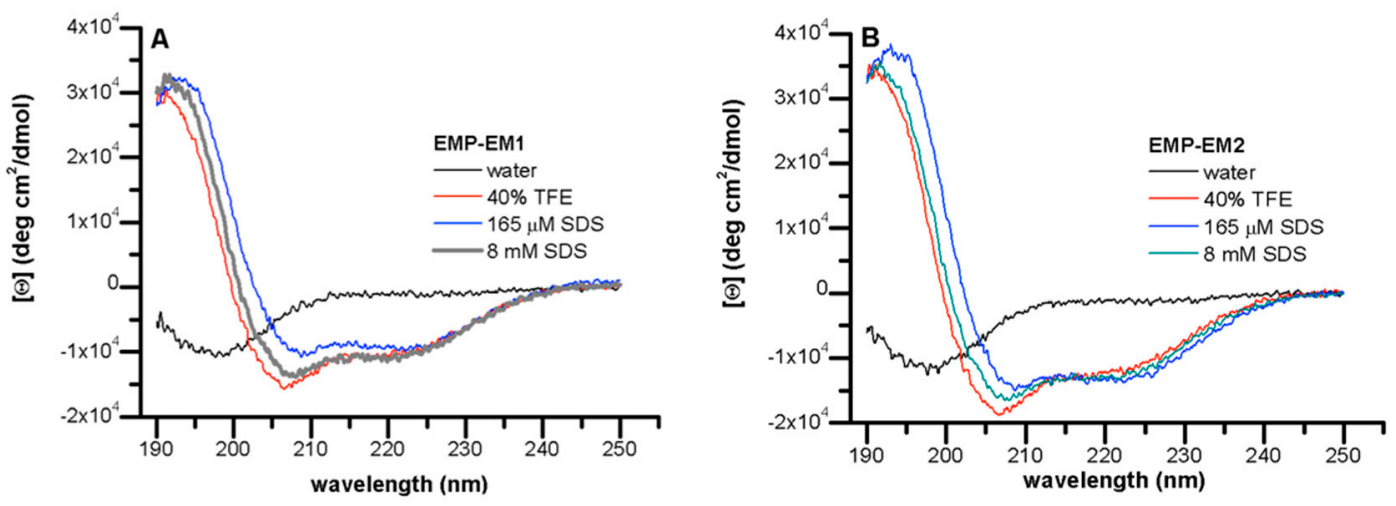

Figure 3. $\mathrm{CD}$ spectra of peptides at $10 \mu \mathrm{M}$, in different environments, at $25{ }^{\circ} \mathrm{C}$. (A) EMP-EM1, (B) EMP-EM2.

Table 7 summarizes CD results and presents physicochemical parameters of EMP-EM1 and EMP-EM2 in comparison to other mastoparan peptides. Except for EMP-AF, all peptides present comparable hydrophobic moments, which is indicative of the amphipaticity of these peptides [26]. EMP-EM1 and EMP-EM-2 present the highest hydrophobicity among these mastoparans, comparable 
to that observed for EMP-EF and EMP-ER, respectively, while showing no hemolytic activity (shown later). The low helical content observed for EMP-EM1 and EMP-EM2 in the presence of PC vesicles is well correlated with the low hemolytic activity. Accordingly, the higher helical content determined in the presence of anionic SDS solutions indicates the relevance of the electrostatic interactions in the interaction of these peptides with model membranes.

Table 7. Physicochemical parameters and $\alpha$-helical content in different environments of EMP-EM1 and EMP-EM2 in comparison to other mastoparan peptides.

\begin{tabular}{|c|c|c|c|c|c|c|c|c|}
\hline \multirow{2}{*}{ Peptides } & \multirow{2}{*}{$\mathbf{N}$} & \multirow{2}{*}{$\mathbf{Q}$} & \multirow{2}{*}{ C-term } & \multirow{2}{*}{$<\mathrm{H}>$} & \multirow{2}{*}{$\mu$} & \multicolumn{3}{|c|}{$f_{H}$} \\
\hline & & & & & & TFE & SDS & PC \\
\hline EMP-EM1 & 14 & +4 & amide & 0.104 & 0.258 & 0.31 & 0.33 & 0.11 \\
\hline EMP-EM2 & 14 & +4 & amide & 0.138 & 0.278 & 0.37 & 0.41 & $<0.03$ \\
\hline EMP-AF ${ }^{1}$ & 14 & +4 & amide & 0.051 & 0.342 & 0.55 & 0.72 & 0.16 \\
\hline EMP-ER $^{2}$ & 14 & +2 & amide & 0.131 & 0.251 & 0.53 & 0.59 & nd \\
\hline EMP-EF ${ }^{2}$ & 14 & +2 & amide & 0.115 & 0.279 & 0.41 & 0.44 & nd \\
\hline
\end{tabular}

$\mathrm{N}$, number of residues; $\mathrm{Q}$, net charge; $\mathrm{C}$-term, $\mathrm{C}$-terminal; $<\mathrm{H}\rangle$, mean hydrophobicity; $\mu$, hydrophobic moment; $f_{\mathrm{H}}, \alpha$-helix fraction: $40 \%$ TFE, $8 \mathrm{mM}$ SDS; $380 \mu \mathrm{M}$ PC; nd, non-determined. (1) dos Santos Cabrera et al., 2004 [9]; (2) Rangel et al., 2011 [13].

\subsection{Biological Activities}

Biological activities of EMP-EM1 and EMP-EM2 were evaluated by using a synthetic specimen. The mast cell degranulation, hemolysis, antimicrobial, and antiprotozoan (leishmanicidal) activities were tested because these are characteristic biological activities for the mastoparan peptide.

Both peptides showed a similar potency of degranulation activity on rat peritoneal mast cells, but it was only moderate at a relatively high concentration $(>30 \mu \mathrm{M})$, and much lower than mastoparan (Figure 4). In contrast, EMP-AF was reported to show more potent activity than mastoparan [8].

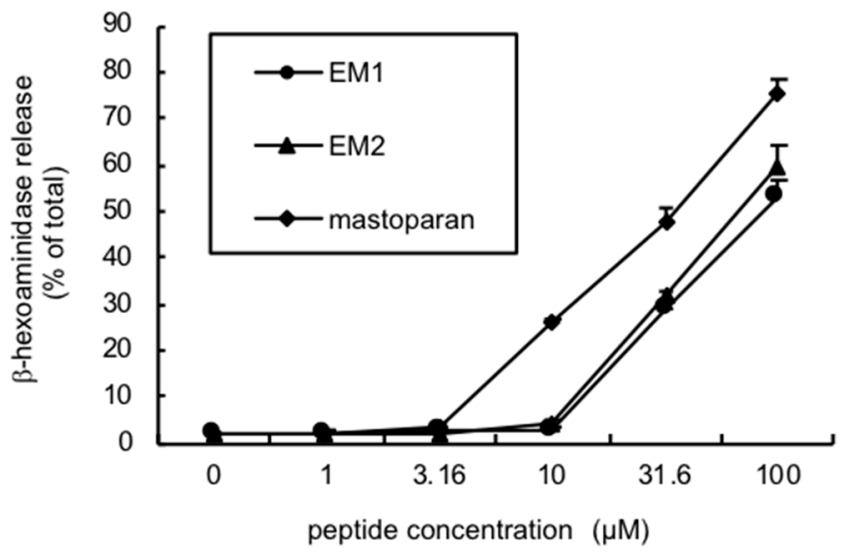

Figure 4. Degranulation activity in rat peritoneal mast cells. The activity was determined by measuring the release of the granule marker, $\beta$-hexosaminidase, which co-localizes with histamine, and the values for $\beta$-hexosaminidase released in the medium were expressed as the percentage of total $\beta$-hexosaminidase, which was determined in the cells lysed in $0.1 \%$ Triton X-100.

The new peptides EMP-EM1 and EMP-EM2 presented no significant hemolytic activity against both human and mouse erythrocytes at the concentration of $10^{-4} \mathrm{M}$, when comparing with other eumenine mastoparan peptides. Mastoparan itself has an $\mathrm{EC}_{50}$ on human erythrocytes of $10^{-5} \mathrm{M}[6]$, while at $10^{-4} \mathrm{M}$ induced $77 \%$ hemolysis on mouse erythrocytes. EMP-AF presented $20 \%$ of the mastoparan activity, with an $\mathrm{EC}_{50}$ of $5 \times 10^{-5} \mathrm{M}$ on human erythrocytes [8]. Other eumenine mastoparan peptides (EMP-ER and EMP-EF) presented moderate hemolytic activity on mouse erythrocytes, with $\mathrm{EC}_{50}$ values of $\sim 2 \times 10^{-4} \mathrm{M}[13]$. 
The new mastoparan peptides showed broad spectrum antibacterial activity. The potency is strong to moderate depending on the species and strain, with the lowest MIC being $3 \mu \mathrm{M}$. However, they are virtually inactive to yeast (Table 8). This trend is similar to that of EMP-AF [8], but in contrast to EMP-ER and EMP-EF, which had more potent activities against yeast [13].

Table 8. Antimicrobial activity of EMP peptides.

\begin{tabular}{|c|c|c|}
\hline \multirow{2}{*}{ Microorganism } & \multicolumn{2}{|c|}{$\operatorname{MIC}(\mu \mathrm{M}) *$} \\
\hline & EM1 & EM2 \\
\hline \multicolumn{3}{|l|}{ Gram-positive } \\
\hline Staphylococcus aureus ATCC 6538 & 34 & 17 \\
\hline Staphylococcus aureus ATCC 25923 & 7 & 3 \\
\hline Staphylococcus saprophyticus (CS) & 3 & 3 \\
\hline Staphylococcus epidermis (CS) & 34 & 34 \\
\hline Bacillus subtilis CCT 2471 & 68 & 68 \\
\hline Bacillus thuringiensis (WT) & $\mathrm{NA}^{* *}$ & NA \\
\hline \multicolumn{3}{|c|}{ Gram-negative } \\
\hline Escherichia coli ATCC 25922 & 7 & 3 \\
\hline Escherichia coli CCT 1371 & 17 & 34 \\
\hline Escherichia cloacae ATCC 23355 & 17 & 34 \\
\hline Proteus mirabilis (CS) & NA & NA \\
\hline Pseudomonas aeruginosa ATCC 15442 & NA & 34 \\
\hline \multicolumn{3}{|l|}{ Yeast } \\
\hline Candida albicans (UMP) & NA & NA \\
\hline
\end{tabular}

Note: ${ }^{*}$ MIC: minimum inhibitory concentration. ${ }^{* *}$ NA: no activity at 67 or $68 \mu \mathrm{M}(100 \mu \mathrm{g} / \mathrm{mL})$.

EMP-EM1 and EMP-EM2 exhibited significant leishmanicidal activity with an $\mathrm{IC}_{50}$ of $36 \mu \mathrm{M}$ against Leishmania major, which is comparable to other eumenine mastoparans (Table 9) [13].

Table 9. Leishmanicidal activity of the mastoparan peptides.

\begin{tabular}{ll}
\hline \multicolumn{1}{c}{ Peptide } & IC50 $(\mu \mathbf{M}){ }^{*}$ \\
\hline EMP-EM1 & 36 \\
EMP-EM2 & 36 \\
EMP-ER & $20^{* *}$ \\
EMP-EF & $40^{* *}$ \\
EMP-AF & $35^{* *}$ \\
\hline$C_{50}: 50 \%$ inhibitory concentration. ${ }^{* *}$ Rangel. M. et al. [11].
\end{tabular}

\section{Discussion}

In this study, we have first analyzed the component profile of the crude venom of Eumenes micado, a solitary eumenine wasp inhabiting Japan, by using LC-MS and MS/MS. It revealed that this venom contained 93 components and that most of them are small peptides. We focused on low molecular weight components in this study because they can be useful for future therapeutic application. That is the reason why the venom components were extracted with $50 \% \mathrm{CH}_{3} \mathrm{CN} / \mathrm{H}_{2} \mathrm{O} / 0.1 \%$. Usually, high molecular weight proteins are not extracted with this condition. However, by using different and appropriate extraction conditions, high molecular weight proteins may be found. In fact, proteins and enzymes, such as arginine kinase, have been found in the venoms of closely related species, Eumenes pomiformis and Orancistrocerus drewseni $[27,28]$.

The peptide sequences were further analyzed by manual analysis of their MS/MS spectra, which led to the determination of a whole sequence of 50 peptides. Among them, four major peptides were thought to be mastoparan peptides due to the sequence similarity and similarity of characteristic 
chemical features to mastoparan. Most of the minor peptides are related to, and a truncated form of, the major mastoparan peptides. It is not certain whether they are constitutive of the venom or degradation products of the new mastoparan peptides. In any case, they are of interest from the viewpoint of structure-activity relationship, which may be a future study. Other than these mastoparan-related peptides, only a few peptides shown in Table 6 are unique peptide components in this venom. However, their function and role in this venom are not clear, since they have no homology or similarity to any known peptides. Peptides with disulfide bridges are common in animal venoms, such as snake, spider, and scorpion venoms, and they play a crucial role in the venom toxicity and functions. In the case of solitary wasp venom, the presence of a novel multiple-cysteine peptide with high homology to known venom peptides, dendrotoxin $(\mathrm{K}+$ channel blocker) and Kuniz-type protease inhibitor, was reported [17]. In contrast, there seems no such type of peptides in this wasp venom, which indicates the distribution of disulfide-bridged peptides is different and depends on species or genus, and evolutional origin.

In addition to the peptides, we identified 25 small molecules (amino acids, biogenic amines, and nucleic acids). It was done easily and simply by LC-MS and MS/MS analysis. Since identification of these small molecules are not easy by the conventional HPLC isolation and identification, the method shown in this study is very useful for this purpose. Most notably, these results were obtained by using only $10 \%$ of the amount of a single venom content. Among the Hymenopteran insect venoms, solitary wasp venom has not been well-documented. One of the reasons why may come from the difficulty of collecting sufficient amounts of venom for chemical analysis because of their solitary lifestyle. However, as shown in this study, the remarkable progress of mass spectrometry in sensitivity made it possible to perform this type of peptidomic analysis with very minute amount of venom.

With these results in hand, we have purified and characterized the major peptide components, EMP-EM1 and EMP-EM2, by the conventional method. The sequences and chemical characteristics of these peptides are similar to the known mastoparan peptides from solitary eumenine wasp venoms, and accordingly, these new peptides belong to mastoparan peptides; in other words, linear cationic $\alpha$-helical peptides. Indeed, the CD spectra of these new peptides showed a predominantly $\alpha$-helix conformation in TFE and SDS.

The biological activities of EMP-EM1 and EMP-EM2 are again similar to those of the known eumenine mastoparan peptides, showing antimicrobial activity and degranulation from mast cells. However, these new peptides showed no significant hemolytic activity to both human and mouse erythrocytes. These results indicated that EMP-EM peptides are strongly associated with bacterial cell membranes rather than mammalian cell membranes. This is in marked contrast to the other eumenine mastoparans, and advantageous for development as therapeutic agents. One of the points of interest for mastoparan peptides is the possible development for a new type of antibiotics due to its potent antimicrobial activity. In this regard, hemolytic activity is a serious drawback as an adverse effect. Accordingly, the new mastoparan peptides found in this study are advantageous and can be a template for further development of new type of antibiotics.

The new mastoparan peptides showed moderate but significant leishmanicidal activity, which is comparable to the known mastoparan peptides from solitary wasp venoms. Leishmaniasis is a parasitic disease caused by protozoal species of the genus Leishmania, and millions of people are afflicted by this disease worldwide. Due to the limitations and drawbacks of the currently available drugs, better, more economical drugs with low toxicity have been long awaited. In this regard, the leishmanicidal activity of the mastoparan peptides is of interest. Since the structure and action mechanism may be quite different from the known drugs, these peptides have a potential as a new type of anti-leishmania agents. 


\section{Materials and Methods}

\subsection{Wasp Collection}

Female wasps of Eumenes micado were collected in Kanagawa, Ibaraki, and Kyoto, Japan. Only the female wasp has sting and venom because sting is evolved from the ovipositor [29]. The collected specimens were immediately frozen by dry ice and kept at $-75^{\circ} \mathrm{C}$ until use. The venom sacs were dissected immediately after being thawed and lyophilized.

\subsection{LC-ESI-MS (Liquid Chromatography-Electrospray Ionization-Mass Spectrometry)}

The crude venom extract with $50 \% \mathrm{CH}_{3} \mathrm{CN} / \mathrm{H}_{2} \mathrm{O} / 0.1 \%$ TFA was analyzed with a LC (Accela 600 Pump, Thermo Scientific, Waltham, MA, USA) connected with ESI-FTMS (LTQ Orbitrap XL, Thermo Scientific). A $10 \%$ amount of crude venom from a single specimen in $10 \mu \mathrm{L}$ water was subjected to reversed-phase HPLC using CAPCELL PAK $\mathrm{C}_{18}$ UG 120, $1.5 \times 150 \mathrm{~mm}$ (SHISEIDO Co., Ltd., Tokyo, Japan) with linear gradient from $5 \%$ to $65 \% \mathrm{CH}_{3} \mathrm{CN} / \mathrm{H}_{2} \mathrm{O} / 0.1 \%$ formic acid at a flow rate of $200 \mu \mathrm{L} / \mathrm{min}$ over $20 \mathrm{~min}$ at $25^{\circ} \mathrm{C}$. ESI-FTMS was operated by Xcalibar ${ }^{\mathrm{TM}}$ software (Thermo Scientific) as: capillary voltage, $+4.6 \mathrm{kV}$; capillary temperature, $350{ }^{\circ} \mathrm{C}$; sheath and aux gas flow, 50 and 30, respectively (arbitrary units). MS/MS spectra were obtained by data dependent MS/MS mode (two most intense peaks by HCD) and the obtained spectra were manually analyzed to give peptide sequences, which were confirmed by MS-Product in the ProteinProspector program (http: / / prospector.ucsf.edu/prospector/cgi-bin/msform.cgi?form=msproduct).

\subsection{Purification of Mastoparan Peptides}

Twelve lyophilized venom sacs were extracted $(5 \times 1 \mathrm{~mL})$ with 1: 1 acetonitrile-water containing $0.1 \%$ TFA $\left(\mathrm{CH}_{3} \mathrm{CN} / \mathrm{H}_{2} \mathrm{O} / 0.1 \%\right.$ TFA), and the extracts were subjected to reverse-phase HPLC (Waters Associates, Milford, MA, USA) using CAPCELL PAK C $18,10 \times 250 \mathrm{~mm}$ (SHISEIDO Co., Ltd., Tokyo, Japan) with linear gradient from $5 \%$ to $95 \% \mathrm{CH}_{3} \mathrm{CN} / \mathrm{H}_{2} \mathrm{O} / 0.1 \%$ TFA at a flow rate of $2.5 \mathrm{~mL} / \mathrm{min}$ over $30 \mathrm{~min}$. The peaks eluted at 21 and $22 \mathrm{~min}$ were manually collected (Figure 1B).

\subsection{Amino Acid Sequencing}

Automated Edman degradation was performed by a gas-phase protein sequencer PPSQ-10 (Shimadzu Corp., Kyoto, Japan).

\subsection{Peptide Synthesis}

Peptides were synthesized on an automated PSSM-8 peptide synthesizer (Shimadzu Corp., Kyoto, Japan) by stepwise solid-phase method using N-9-fluorenylmethoxycarbonyl (Fmoc) chemistry. All the resins and Fmoc-L-amino acids were purchased from Nova Biochem (UK). Cleavage of the peptide from the resin was achieved by treatment with a mixture of TFA/1,2-ethanedithiol/thioanisole/phenol/ethyl methyl disulfide/water (82:3:5:3:2:5, by volume) using $10 \mathrm{~mL} / \mathrm{g}$ resin at room temperature for $8 \mathrm{~h}$. After removal of the resin by filtration and washing twice with TFA, the combined filtrate was added dropwise to diethyl ether at $0{ }^{\circ} \mathrm{C}$ and then centrifuged at $3000 \mathrm{rpm}$ for $10 \mathrm{~min}$. Thus, the obtained crude synthetic peptide was purified by semipreparative reverse-phase HPLC using CAPCELL PAK $\mathrm{C}_{18}, 10 \times 250 \mathrm{~mm}$ with isocratic elution of $42 \% \mathrm{CH}_{3} \mathrm{CN} / \mathrm{H}_{2} \mathrm{O} / 0.1 \% \mathrm{TFA}$ at a flow rate of $2.5 \mathrm{~mL} / \mathrm{min}$. The homogeneity and the sequence were confirmed by LC-MS.

\subsection{Circular Dichroism (CD) measurements}

CD spectra were acquired over 190-250 nm, using a Jasco-710 spectropolarimeter (JASCO International Co. Ltd., Tokyo, Japan) regularly calibrated using d-10-camphorsulfonic acid. Spectra were obtained at $25^{\circ} \mathrm{C}$ using $0.5 \mathrm{~cm}$ quartz cells in the following environments: in water; in a $40 \%$ 
solution of 2,2,2, trifluoroethanol (40\% TFE, from Merck, Darmstadt, Germany); in SDS solutions below $(165 \mu \mathrm{M})$ and above the critical micellar concentration $(8 \mathrm{mM})$; and in the presence of PC vesicles at $240 \mu \mathrm{M}$. Stock solutions of peptides were prepared in ultra-pure water. CD spectra were recorded at $10 \mu \mathrm{M}$ concentration, at a scan speed of $20 \mathrm{~nm} / \mathrm{min}$, bandwidth of $1.0 \mathrm{~nm}, 0.5 \mathrm{~s}$ response, and 0.1 $\mathrm{nm}$ resolution. Six repeat scans were accumulated to make up the final averaged spectra. Following baseline correction, the observed ellipticity, $\theta$ (mdeg) was converted to mean residue ellipticity $[\Theta]$ ( $\left.\mathrm{deg} \mathrm{cm}^{2} / \mathrm{dmol}\right)$, using the relationship $[\Theta]=100 \theta /(\mathrm{c} \mathrm{n})$, where " 1 " is the path length in centimeters, " $\mathrm{c}$ " is peptide millimolar concentration, and " $\mathrm{n}$ " the number of residues in the peptide. The $\alpha$-helix fractions were determined according to the Rohl and Baldwin [30] assuming the two-state model.

\subsection{Mast Cell Degranulation Activity ( $\beta$-Hexosaminidase Assay)}

Mast cells were obtained by peritoneal lavage of adult ( $>300 \mathrm{~g})$ Sprague-Dawley rats. The mast cells were isolated from containing cell types by centrifugation through a cushion of Percoll as previously described [31], washed twice by resuspension and centrifugation, and finally suspended in a HEPES buffer, which was comprised of $137 \mathrm{mM} \mathrm{NaCl}, 2.7 \mathrm{mM} \mathrm{KCl}, 1 \mathrm{mM} \mathrm{MgCl}$, $1.8 \mathrm{mM} \mathrm{CaCl}_{2}$, $20 \mathrm{mM}$ HEPES, $1 \mathrm{mg} / \mathrm{mL}$ BSA, and $1 \mathrm{mg} / \mathrm{mL}$ glucose (pH 7.4).

Degranulation was determined by measuring the release of the granule marker, $\mathrm{N}$-acetyl- $\beta$-D-glucosaminidase ( $\beta$-hexosaminidase), which co-localizes with histamine, as previously described [31]. The cells were incubated with various concentration of the peptide for $15 \mathrm{~min}$ at $37^{\circ} \mathrm{C}$, and then the cells were quenched by addition of $0.15 \mathrm{~mL}$ of ice-cold HEPES buffer. After centrifugation, the supernatants were sampled for $\beta$-hexosamnidase assay. Briefly, $50 \mathrm{~mL}$ of samples of the medium and $50 \mathrm{~mL}$ of the substrate, $5 \mathrm{mM} p$-nitrophenyl- $N$-acetyl- $\beta$-D-glucosaminide (Sigma Chemical Co., St. Louis, MO, USA) in $0.2 \mathrm{M}$ citrate, $\mathrm{pH} 4.5$, were incubated in 96-well plates to yield the chromophore, $p$-nitrophenol. The absorbance of the colored product was assessed at $405 \mathrm{~nm}$ using a microtiter plate reader. The values for $\beta$-hexosaminidase released in the medium were expressed as the percentage of total $\beta$-hexosaminidase, which was determined in the cells lysed in $0.1 \%$ Triton $\mathrm{X}-100$.

\subsection{Hemolytic Assay}

Human erythrocytes - Hemolytic assay was performed as previously described [32] with slight modification. Human blood was obtained from healthy donors at the Vital Brasil Hospital in Butantan Institute. Blood samples drawn to obtain erythrocytes for subsequent use as target cells were collected in anticoagulant (Alsever's old solution, containing, in $\mathrm{mM}, 114$ citrate, 27 glucose and $72 \mathrm{NaCl}$, $\mathrm{pH}$ 6.1). Erythrocytes were washed three times, resuspended at $2 \%$ in PBS, and incubated with sample for $30 \mathrm{~min}$ at $37^{\circ} \mathrm{C}$. Background or total cell lysis was evaluated by incubation of erythrocytes with PBS or Triton X-100 $(0.5 \%)$, respectively. After incubation, unlysed cells were spun down and the absorbance of the supernatant was measured at 414 and $540 \mathrm{~nm}$ and expressed as percentage of lysis.

Mouse erythrocytes-A 4\% suspension of mouse erythrocytes (ES) was prepared as described [33]. Different concentrations of the peptides were incubated with the ES at room temperature $\left(\sim 22{ }^{\circ} \mathrm{C}\right)$ in an Elisa plate (96-wells). After $1 \mathrm{~h}$ it was centrifuged (1085 $\mathrm{g} / 5 \mathrm{~min})$, and the hemolytic activity of the supernatant was measured by the absorbance at $540 \mathrm{~nm}$, considering as blank the absorbance of Krebs-Henseleit physiological solution (mM: NaCl 113; $\mathrm{KH}_{2} \mathrm{PO}_{4} 1.2 ; \mathrm{KCl} 4 ; \mathrm{MgSO}_{4} 1.2 ; \mathrm{CaCl}_{2} 2.5$; $\mathrm{NaHCO}_{3} 25$; glucose 11.1), which was the vehicle for the peptides. Total hemolysis was obtained with $1 \%$ Triton X-100 and the percentage of hemolysis was calculated relative to this value.

All tests were performed in quadruplicates.

\subsection{Antimicrobial Activity (Determination of Minimal Inhibitory Concentration, MIC)}

The microorganisms used were: Staphylococcus aureus (ATCC 6538, ATCC 25923). S. saprophyticus (clinical species), Bacillus subtilis (CCT 2471), B. thuringiensis (wild species), Echerichia coli (CCT 1371), E. coli (ATCC 25922), Enterobacter cloacae (ATCC 23355), Proteus mirabilis (clinical species), Pseudomonas aeruginosa (ATCC 15442), and Candida albicans (UMP). 
Müeler-Hinton broth was from Difco. Serial dilution of peptide was prepared in sterilized water. Aliquots were placed in ELISA microplates containing Müeler-Hinton broth in a final volume of $200 \mu \mathrm{L}$. The mixture was completed by inoculation of $10 \mu \mathrm{L}$ of bacterial culture growing in logarithmic-phase of microorganism, as monitored by the UV absorbance at $600 \mathrm{~nm}$. The final cells number $\left(1 \times 10^{5} / \mathrm{mL}\right)$ was determined by plate counting.

The plates were incubated at $35^{\circ} \mathrm{C}$ and aliquots of $10 \mu \mathrm{L}$ were removed both at the beginning of assay and after overnight incubation, and then plated in Müeler-Hinton agar. The number of colony-forming units was determined. The results were expressed as inhibition percentage of colony-forming units against a control; this control was obtained in each situation by counting the number of microorganisms introduced into the plate in the absence of peptide.

\subsection{Leishmanicidal Activity}

Medium 199 was used for the cultivation of promastigotes of Leishmania major (MHOM/SU/73/5ASKH). Promastigotes were cultured in the medium (supplemented with heat-inactivated $\left(56{ }^{\circ} \mathrm{C}\right.$ for $30 \mathrm{~min}$ ) fetal bovine serum $(10 \%)$ ) at $27^{\circ} \mathrm{C}$, in a $5 \% \mathrm{CO}_{2}$ atmosphere in an incubator [34].

The leishmanicidal effects of the peptides were assessed using the improved 3-[4,5-dimethylthiazol-2-yl]-2,5-diphenyltetrasodium bromide (MTT) method, as follows. Cultured promastigotes were seeded at $4 \times 10^{5} / 50 \mu \mathrm{L}$ of the medium per well in 96-well microplates, and then $50 \mu \mathrm{L}$ of different concentrations of test compounds dissolved in a mixture of DMSO and the medium were added to each well. Each concentration was tested in triplicate. The microplate was incubated at $27^{\circ} \mathrm{C}$ in $5 \% \mathrm{CO}_{2}$ for $48 \mathrm{~h}$. Tetra Color ONE $(10 \mu \mathrm{L})$ (a mixture of WST-8 (2-(2-methoxy-4-nitrophenyl)-3-(4-nitrophenyl)-5-(2,4-disulfophenyl)-2 $H$-tetrazolium, monosodium salt) and 1-methoxy PMS (1-methoxy-5-methylphenazinium methosulfate9)) was added to each well and the plates were incubated at $27{ }^{\circ} \mathrm{C}$ for $6 \mathrm{~h}$. Optical density values (test wavelength $450 \mathrm{~nm}$; reference wavelength $630 \mathrm{~nm}$ ) were measured using a microplate reader (Thermo BioAnalysis Japan Co., Ltd., Kanagawa, Japan). The values of $50 \%$ inhibitory concentration of the peptides were estimated from the dose-response curve.

Author Contributions: K.K. (Katsuhiro Konno) and K.K. (Kohei Kazuma) performed LC-MS and MS/MS spectral analysis. M.R. examined hemolytic activity and performed CD experiments. J.S.d.O. examined hemolytic activity. R.F. examined antimicrobial activity. M.K. and H.F. examined leishmanicidal activity. I.H. and Y.N. examined mast cell degranulation activity. T.Y. performed peptide sequence analysis and peptide synthesis. K.K. (Katsuhiro Konno) and M.R. wrote the paper.

Funding: A part of this work was financially supported by the JSPS KAKENHI Grant Number 15K07805, Grant-in-Aid for Scientific Research from the Ministry of Education, Culture, Sports, Science, and Technology (MEXT) of Japan.

Acknowledgments: We would like to thank João Ruggiero Neto and Marcia Perez dos Santos Cabrera (Department of Physics, Institute of Biosciences, Letters, and Exact Sciences, São Paulo State University) for the use of the CD equipment, assistance with experiments, and helpful discussions.

Conflicts of Interest: The authors declare no conflict of interest.

\section{References}

1. Hirai, Y.; Yasuhara, T.; Yoshida, H.; Nakajima, T.; Fujino, M.; Kitada, C. A new mast cell degranulating peptide "mastoparan" in the venom of Vespula lewisii. Chem. Pharm. Bull. 1979, 27, 1942-1944. [CrossRef] [PubMed]

2. Nakajima, T. Pharmacological biochemistry of vespid venoms. In Venoms of the Hymenoptera: Biochemical, Pharmacological and Behavioural Aspects; Piek, T., Ed.; Academic Press: London, UK, 1986; pp. 309-327, ISBN 0-12-554771-4.

3. Murata, K.; Shinada, T.; Ohfune, Y.; Hisada, M.; Yasuda, A.; Naoki, H.; Nakajima, T. Novel biologically active peptides from the venom of Polistes rothneyi iwatai. Biol. Pharm. Bull. 2006, 29, 2493-2497. [CrossRef] [PubMed] 
4. Moreno, M.; Giralt, E. Three valuable peptides from bee and wasp venoms for therapeutic and biotechnological use. Toxins 2015, 7, 1126-1150. [CrossRef] [PubMed]

5. Chen, X.; Zhang, L.; Wu, Y.; Wang, L.; Ma, C.; Xi, X.; Bininda-Emonds, O.R.P.; Shaw, C.; Chen, T.; Zhou, M. Evaluation of the bioactivity of a mastoparan peptide from wasp venom and of its analogues designed through targeted engineering. Int. J. Biol. Sci. 2018, 14, 599-607. [CrossRef] [PubMed]

6. Howl, J.; Howl, L.; Jones, S. The cationic tetradecapeptide mastoparan as a privileged structure for drug discovery: Enhanced antimicrobial properties of mitoparan analogues modified at position-14. Peptides 2018, 101, 95-105. [CrossRef] [PubMed]

7. Konno, K.; Kazuma, K.; Nihei, K. Peptide toxins in solitary wasp venoms. Toxins 2016, 8, 114. [CrossRef] [PubMed]

8. Konno, K.; Hisada, M.; Naoki, H.; Itagaki, Y.; Kawai, N.; Miwa, A.; Yasuhara, T.; Morimoto, Y.; Nakata, Y. Structure and biological activities of eumenine mastoparan-AF (EMP-AF), a novel mast cell degranulating peptide in the venom of the solitary wasp (Anterhynchium flavomarginatum micado). Toxicon 2000, 38, 1505-1515. [CrossRef]

9. Cabrera, M.P.S.; Souza, B.M.; Fontana, R.; Konno, K.; Palma, M.S.; de Azevedo, W.F., Jr.; Ruggiero Neto, J. Conformation and lytic activity of eumenine mastoparan: A new antimicrobial peptide from wasp venom. J. Peptide Res. 2004, 64, 95-103. [CrossRef] [PubMed]

10. Sforça, M.L.; Oyama, S., Jr.; Canduri, F.; Lorenzi, C.C.B.; Pertinez, T.A.; Konno, K.; Souza, B.M.; Palma, M.S.; Ruggiero Neto, J.; de Azevedo, W.F., Jr.; et al. How C-terminal carboxyamidation alters the mast cell degranulating activity of peptides from the venom of the eumenine solitary wasp. Biochemistry 2004, 43, 5608-5617. [CrossRef] [PubMed]

11. Murata, K.; Shinada, T.; Ohfune, Y.; Hisada, M.; Yasuda, A.; Naoki, H.; Nakajima, T. Novel mastoparan and protonectin analogs isolated from a solitary wasp, Orancistrocerus drewseni drewseni. Amino Acids 2009, 37, 389-394. [CrossRef] [PubMed]

12. Baek, J.H.; Lee, S.H. Isolation and molecular cloning of venom peptides from Orancistrocerus drewseni (Hymenoptera: Eumenidae). Toxicon 2010, 55, 711-718. [CrossRef] [PubMed]

13. Rangel, M.; Cabrera, M.P.S.; Kazuma, K.; Ando, K.; Wang, X.; Kato, M.; Nihei, K.; Hirata, I.Y.; Cross, T.; Garcia, A.N.; et al. Chemical and biological characterization of four new antimicrobial and $\alpha$-helical peptides from the venoms of two solitary eumenine wasps. Toxicon 2011, 57, 1081-1092. [CrossRef] [PubMed]

14. Baek, J.H.; Lee, S.H. Differential gene expression profiles in the venom gland/sac of Eumenes pomiformis (Hymenoptera: Eumenidae). Toxicon 2010, 55, 1147-1156. [CrossRef] [PubMed]

15. Kuhn-Nentwig, L. Antimicrobial and cytolytic peptides of venomous arthropods. Cell. Mol. Life Sci. 2003, 60, 2651-2668. [CrossRef] [PubMed]

16. Nakajima, T.; Yasuhara, T.; Yoshida, N.; Takemoto, Y.; Shinonaga, S.; Kano, R.; Yoshida, H. The pattern analysis of biologically active amines in some Hymenopteran venoms by high performance liquid chromatography. Jpn. J. Sanit. Zool. 1983, 34, 61-71. [CrossRef]

17. Hisada, M.; Satake, H.; Masuda, K.; Aoyama, M.; Murata, K.; Shinada, T.; Iwashita, T.; Ohfune, Y.; Nakajima, T. Molecular components and toxicity of the venom of the solitary wasp, Anoplius samariensis. Biochem. Biophys. Res. Commun. 2005, 330, 1048-1054. [CrossRef] [PubMed]

18. Moore, E.L.; Arvidson, R.; Banks, C.; Urenda, J.P.; Duong, E.; Mohammed, H.; Adams, M.E. Ampulexins: A new family of peptides in venom of the emerald jewel wasp, Ampulex compressa. Biochemistry 2018, 57, 1907-1916. [CrossRef] [PubMed]

19. Konno, K.; Hisada, M.; Naoki, H.; Itagaki, Y.; Yasuhara, T.; Juliano, M.A.; Juliano, L.; Palma, M.S.; Nakajima, T. Isolation and sequence determination of peptides in the venom of the spider wasp Cyphononyx dorsalis guided by matrix-assisted laser desorption/ionization time of flight (MALDI-TOF) mass spectrometry. Toxicon 2001, 39, 1257-1260. [CrossRef]

20. Wakamatsu, K.; Okada, A.; Miyazawa, T.; Ohya, M.; Higashijima, T. Membrane-bound conformation of Mastoparan-X, a G protein-activating peptide. Biochemistry 1992, 31, 5654-5660. [CrossRef] [PubMed]

21. Hori, Y.; Demura, M.; Iwadate, M.; Ulrich, A.S.; Niidome, T.; Aoyagi, H.; Asakura, T. Interaction of mastoparan with membranes studied by ${ }^{1} \mathrm{H}-\mathrm{NMR}$ spectroscopy in detergent micelles and by solid-state ${ }^{2} \mathrm{H}-\mathrm{NMR}$ and ${ }^{15} \mathrm{~N}-\mathrm{NMR}$ spectroscopy in oriented lipid bilayers. Eur. J. Biochem. 2001, 268, 302-309. [CrossRef] [PubMed] 
22. Todokoro, Y.; Yumen, I.; Fukushima, K.; Kang, S.W.; Park, J.S.; Kohno, T.; Wakamatsu, K.; Akutsu, H.; Fujiwara, T. Structure of tightly membrane-bound Mastoparan-X, a G-protein-activating peptide, determined by solid-state NMR. Biophys. J. 2006, 91, 1368-1379. [CrossRef] [PubMed]

23. Wimley, W.C. Describing the mechanism of antimicrobial peptide action with the interfacial activity model. ACS Chem. Biol. 2010, 5, 905-917. [CrossRef] [PubMed]

24. Park, N.G.; Yamato, Y.; Lee, S.; Sugihara, G. Interaction of mastoparan-B from venom of a hornet in Taiwan with phospholipid bilayers and its antimicrobial activity. Biopolymers 1995, 36, 793-801. [CrossRef] [PubMed]

25. Blondelle, S.E.; Forood, B.; Houghten, R.A.; Pérez-Payá, E. Secondary structure induction in aqueous vs. membrane-like environments. Biopolymers 1997, 42, 489-498. [CrossRef]

26. Eisenberg, D.; Schwarz, E.; Komaromy, M.; Wall, R. Analysis of membrane and surface protein sequences with the hydrophobic moment plot. J. Mol. Biol. 1984, 179, 125-142. [CrossRef]

27. Baek, J.H.; Lee, S.H. Identification and characterization of venom protein of two solitary wasps, Eumenes pomiformis and Orancistrocerus drewseni. Toxicon 2010, 56, 554-562. [CrossRef] [PubMed]

28. Lee, S.H.; Baek, J.H.; Yoon, K.A. Differential properties of venom peptides and proteins in solitary vs. social hunting wasps. Toxins 2016, 8, 32. [CrossRef] [PubMed]

29. Marle, J.V.; Piek, T. Morphology of the venom apparatus. In Venoms of the Hymenoptera: Biochemical, Pharmacological and Behavioural Aspects; Piek, T., Ed.; Academic Press: London, UK, 1986; pp. 17-44.

30. Rohl, C.A.; Baldwin, R.L. Deciphering rules of helix stability in peptides. Methods Enzymol. 1998, 295, 1-26. [CrossRef] [PubMed]

31. Hide, I.; Bennett, J.P.; Pizzey, A.; Boonen, G.M.; Bar-Sagi, D.; Gomperts, B.D.; Tatham, P.E.R. Degranulation of individual mast cells in response to $\mathrm{Ca}^{2+}$ and guanine nucleotides: An all-or-none event. J. Cell Biol. 1993, 123, 585-593. [CrossRef] [PubMed]

32. Oliveira, K.C.; Andrade, R.M.A.; Piazza, R.M.F.; Ferreira, J.M.C., Jr.; Berg, C.W.; Tambourgi, D.V. Variations in Loxosceles spider venom composition and toxicity contribute to the severity of envenomation. Toxicon 2005, 45, 421-429. [CrossRef] [PubMed]

33. Rangel, M.; Malpezzi, E.L.A.; Susini, S.M.M.; Freitas, J.C. Hemolytic activity in extracts of the diatom Nitzschia. Toxicon 1997, 35, 305-309. [CrossRef]

34. Takahashi, M.; Fuchino, H.; Satake, M.; Agatsuma, Y.; Sekita, S. In vitro screening of leishmanicidal activity of Myanmar timber extracts. Biol. Pharm. Bull. 2004, 27, 921-925. [CrossRef] [PubMed] 